\title{
Sistem Informasi Pengadaan Barang pada Rumah Sakit Umum Daerah Sawahlunto dengan Menggunakan Bahasa Pemrograman Java Didukung oleh Database MySql
}

\author{
Ramalia Noratama Putri \\ DosenTeknik Informatika STMIK AMIK RIAU \\ ramalianoratamaputri@yahoo.com
}

\begin{abstract}
ABSTRAK
Pemanfaatan teknologi komputer dalam pengadaan barang pada Rumah Sakit Umum Daerah Swahlunto belum efektif dan efisien sehingga dalam pembuatan laporan barang habis pakai dan inventaris membutuhkan waktu yang lama.Dengan menggunakan desain sistem yang baru untuk membantu dalam pengadaan barang, menghasilkan suatu sistem yang diinginkan maka dibuatlah suatu sistem yaitu dengan menggunakan bahasa Pemrograman Java berbasis Database MySQL.Dalam hal ini penulis menggunakan beberapa metode dalam mengumpulkan data diantaranya adalah penelitian lapangan, dan penelitian perpustakan. Dimana data-data yang diperoleh dikelompokan terlebih dahulu dan dalam analisa dan hasil digunakan Aliran system Informasi (ASI), Contex Diagram, Data Flow Diagram (DFD), Entity Relationship Diagram(ERD), dan Flowchart yag didukung dengan alat Bantu komputer sehingga menghasilkan database.Diterapkan sistem yang baru ini nantinya akan meningkatkan kualitas informasi yang dihasilkan sehingga rancangan-rancangan tersebut dapat bermanfaat bagi Rumah sakit Umum Daerah Sawahlunto.
\end{abstract}

Kata kunci: Sistem informasi, Pengadaan, Pemrograman Java, Database MySQL

\section{PENDAHULUAN}

\subsection{Latar Belakang Masalah}

Seiring dengan perkembangan teknologi informasi, suatu perusahaan atau organisasi dituntut untuk dapat saling meningkatkan mutu dan kualitas sistem informasinya, agar bisa bersaing dalam persaingan di era globalisasi. Dengan adanya penggunaan teknologi informasi secara optimal maka jelas sekali akan menunjang dalam peningkatan kualitas sistem informasi yang ada dalam perusahaan

Rumah Sakit Umum Daerah Sawahlunto merupakan sebuah organisasi yang bergerak dalam bidang pelayanan kesehatan yang memberikan pelayanan umum pada masyarakat luas baik itu di Sawahlunto ataupun diluar kota Sawahlunto. 
Penelitian Bidang Komputer Sains dan Pendidikan Informatika V2.i1(63-78)

Oleh karena itu yang perlu diperhatikan untuk menjaga dan mengetahui tingkat persediaan dari suatu barang perlu diadakan sistem informasi pengadaan barang yang baik. Seperti halnya pada Rumah Sakit Umum Daerah Sawahlunto dalam pengadaan barang yang dibutuhkan. Selama ini pihak pengadaan barang masih melakukan sistem yang manual, misalnya pada pencatatan barang yang dibutuhkan dan dalam pelaporan mengenai barang-barang yang telah digunakan. Dengan begitu, pihak gudang membutuhkan waktu yang lama dalam pencatatan laporan dan dalam hal pengadaan barang yang dibutuhkan. Begitu juga dalam mengetahui persediaan yang ada di gudang, pihak gudang harus melihat dan menghitung barang yang masih tersedia di gudang, sehingga membutuhkan waktu yang lama.

\subsection{Perumusan Masalah}

Dalam penulisan ini akan dibahas masalah mengenai:

1. Bagaimana cara memperbaiki proses pengolahan data barang yang akan di order serta menghitung sisa barang yang masih ada di gudang, dan jumlah permintaan barang setiap ruangan yang ada di Rumah Sakit Umum Daerah Sawahlunto dengan membangun sebuah sistem informasi berbasis komputer?
2. Bagaimana cara membangun sebuah sistem yang dapat membantu pihak gudang dalam mendistribusikan barang ke setiap ruangan ?

3. Bagaimana cara membuat sistem informasi berbasis komputer dalam memproses laporan BHP (Barang Habis Pakai) dan seluruh stock opname perhari, perbulan, dan pertahun?

4. Bagaimana cara membuat sistem informasi berbasis komputer dalam memproses laporan inventaris barang persemester?

\subsection{Tujuan Penelitian}

Tujuan penelitian adalah sebagai berikut :

1. Untuk mempelajari dan menganalisa Sistem Informasi Pengadaan Barang pada Rumah Sakit Umum Daerah Sawahlunto.

2. Mendesain dan menguji Sistem Informasi Pengadaan Barang pada Rumah Sakit Umum Daerah Sawahlunto.

3. Mengevaluasi Sistem Informasi Pengadaan Barang pada Rumah Sakit Umum Daerah Sawahlunto.

\section{LANDASAN TEORI}

\subsection{Pengertian Sistem Informasi}

Menurut (Jogiyanto. HM, 2008 : 
Penelitian Bidang Komputer Sains dan Pendidikan Informatika V2.i1(63-78)

11), Sistem informasi adalah suatu sistem di

dalam suatu organisasi yang mempertemukan kebutuhan pengolahan transaksi harian, mendukung operasi, bersifat manajerial dan kegiatan strategi dari suatu organisasi dan menyediakan pihak luar tertentu dengan laporan-laporan yang diperlukan.

\subsection{Aliran Sistem Informasi (ASI)}

Aliran sistem informasi merupakan bagan alir yang menunjukan arus dari program dan formulir termasuk tembusantembusannya. Aliran sistem informasi mempunyai simbol-simbol.Sebagian simbolsimbol yang akan digunakan dalam menggambarkan aliran sistem informasi dapat dilihat pada tabel 2.1

Tabel 2.1. Simbol-Simbol Pada Aliran Sistem Informasi

\begin{tabular}{|c|c|c|}
\hline Gambar & Keterangan & Fungsi \\
\hline & $\begin{array}{l}\text { Simbol } \\
\text { proses }\end{array}$ & $\begin{array}{l}\text { Menunjukkan } \\
\text { proses }\end{array}$ \\
\hline & $\begin{array}{l}\text { Simbol } \\
\text { alternative }\end{array}$ & $\begin{array}{l}\text { Menunjukan } \\
\text { alternative }\end{array}$ \\
\hline & $\begin{array}{l}\text { Simbol } \\
\text { multi } \\
\text { dokumen }\end{array}$ & $\begin{array}{l}\text { Menunjukan } \\
\text { dokumen } \\
\text { input dan } \\
\text { ouput untuk } \\
\text { proses } \\
\text { manual, } \\
\text { mekanik atau } \\
\text { komputer }\end{array}$ \\
\hline 7 & Simbol & Menunjukan \\
\hline
\end{tabular}

\begin{tabular}{|l|l|l|}
\hline & $\begin{array}{l}\text { kegiatan } \\
\text { manual }\end{array}$ & $\begin{array}{l}\text { pekerjaan } \\
\text { manual }\end{array}$ \\
\hline penghubung & $\begin{array}{l}\text { Simbol } \\
\text { penghunjukan } \\
\text { dalam satu } \\
\text { halaman }\end{array}$ \\
\hline & $\begin{array}{l}\text { Simbol } \\
\text { simpanan } \\
\text { offline }\end{array}$ & $\begin{array}{l}\text { Menunjukan } \\
\text { simpan data } \\
\text { secara } \\
\text { manual }\end{array}$ \\
\hline \multirow{2}{*}{$\begin{array}{l}\text { Simbol hard } \\
\text { disk }\end{array}$} & $\begin{array}{l}\text { Menunjukan } \\
\text { penyimpanan } \\
\text { data secara } \\
\text { elektronik }\end{array}$ \\
\hline & $\begin{array}{l}\text { Simbol } \\
\text { garis alir }\end{array}$ & $\begin{array}{l}\text { Menunjukan } \\
\text { arus dari } \\
\text { proses }\end{array}$ \\
\hline
\end{tabular}

\subsection{Data Flow Diagram (DFD)}

DFD menggambarkan sistem yang sedang berjalan dan diusulkan secara logika tanpa mempertimbangkan lingkungan fisik data. DFD memiliki beberapa simbol yaitu :

Tabel 2.2. Simbol-Simbol Pada Flow

\begin{tabular}{|c|l|l|}
\multicolumn{2}{|c}{ Diagram (DFD) } \\
\hline Simbol & Keterangan & \multicolumn{1}{|c|}{ Fungsi } \\
\hline \hline & $\begin{array}{l}\text { Simbol } \\
\text { proses }\end{array}$ & $\begin{array}{l}\text { Menunjukan } \\
\text { kegiatan } \\
\text { dari proses } \\
\text { komputer }\end{array}$ \\
\hline & $\begin{array}{l}\text { Simbol } \\
\text { entitas }\end{array}$ & $\begin{array}{l}\text { Menunjukan } \\
\text { suatu entitas } \\
\text { atau entity }\end{array}$ \\
\hline & Simbol & Menunjukan \\
\hline
\end{tabular}


Penelitian Bidang Komputer Sains dan Pendidikan Informatika

\begin{tabular}{|l|l|l|}
\hline$\longleftarrow$ & aliran data & $\begin{array}{l}\text { aliran atau } \\
\text { arus dari } \\
\text { proses }\end{array}$ \\
\hline \hline & Simbol file & $\begin{array}{l}\text { Untuk } \\
\text { menyimpan } \\
\text { data }\end{array}$ \\
\hline
\end{tabular}

\subsection{Konsep Dasar Database}

Adapun pengertian database banyak dikemukanan oleh para ahli komputer. Pengertian databaseterbagi dua yaitu:

Secara Umum yaitu:

1. Adanya kumpulan data dalam jumlah yang besar tersimpan dalam mediumseperti harddisk, pita magnetik, floppy disk, dan lain-lain.

2. Berkenaan dengan kumpulan data tersebut terdapat seperangkat program aplikasi yang dilakukan secara bacth yang melakukan operasi retrive, update, insert, dan delete.

Database adalah sekumpulan data / informasi yang teratur berdasarkan kriteria tertentu yang saling berhubungan. Dalam dunia komputer bisa dikatagorikan sangat spesial karena selalu menjadi hal utama dalam perancangan sistem komputer suatu perusahaan. Database menjadi perioritas dalam kinerja manajemen perusahaan, diantaranya:
1. Database tidak hanya berisi data tetapi juga berisi rencana atau model data.

2. Database dapat menjadi sumber utama yang digunakan secarabersama-sama oleh berbagai pemakai dalam perusahaan sesuai dengan kebutuhan.

\subsection{Keuntungan Database}

1. Data yang tersimpan dapat dipergunakan secara bersamaan.

2. Tingkat redudancy (kemubaziran) data dapat dikurangi.

3.Inkosistem (ketidakcocokan) data sampai batas-batas tertentu.

\section{ANALISA DAN HASIL}

\subsection{Analisa Sistem Yang Sedang Berjalan}

Gudang Rumah Sakit Umum Daerah Sawahlunto pada saat sekarang ini belum menggunakan komputer sebagai alat pengolahan datanya. Dimana dalam proses pembuatan laporan dan pada proses pengadaan ke ruangan masih menggunakan sistem manual. Ini tentunya akan memperlambat proses pengolahan data untuk pembuatan laporan serta proses pengendalian pada barang di gudang sehingga tidak tercapainya efektifitas dan efesiensi kerja. 


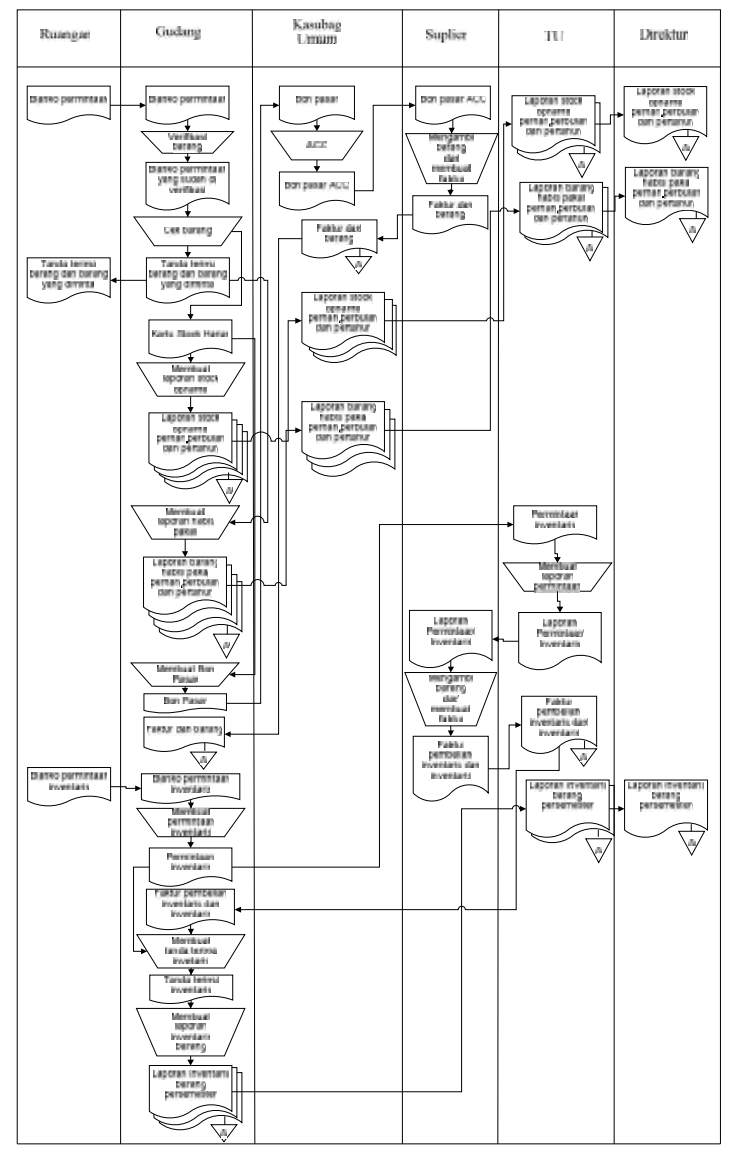

Gambar 3.1 AliranSistemInformasi(ASI)

Lama Pengadaan Barang Rumah Sakit Umum Daerah Sawahlunto

\subsubsection{Evaluasi Sistem yang Ada}

Berdasarkan sistem yang sedang berjalan saat ini pada Rumah Sakit Umum Daerah Sawahlunto terdapat beberapa masalah.

1. Selama ini Pihak Gudang dalam menghitung sisa barang yang ada di gudang dengan cara mencatat jumlah barang keluar ke dalam kartu stock opname, hal ini memberikan kesulitan pada pihak gudang, misalnya apabila terjadi kesalahan pada pencatatan barang yang keluar, maka terjadi pula kesalahan terhadap jumlah sisa barang yang ada di gudang, sehingga informasi mengenai sisa barang yang ada di gudang menjadi salah. Dengan demikian jumlah barang yang akan dipesan yaitu pada bon pasar, juga terjadi kesalahan. Masalah ini juga menyulitkan pihak gudang dalam hal pembuatan laporan stock opname. Selama ini proses pembuatan laporan berdasarkan kartu stock opname, apabila terjadi kesalahan pencatatan pada kartu stock opname maka laporan stock opname juga mengalami kesalahan mengenai jumlah barang yang tersedia di gudang.

2. Dalam hal pendistribusian barang dari gudang ke setiap ruangan, selama ini pihak gudang menggunakan blanko permintaan untuk mengetahui jumlah permintaan dan jumlah barang yang telah di distribusikan ke ruangan, sehingga apabila terjadi kesalahan dalam pencatatan jumlah permintaan pada blanko permintaan dan pada tanda terima maka informasi mengenai jumlah permintaan menjadi salah. Dengan demikian pada laporan mengenai laporan 
barang habis pakai juga terjadi kesalahan, karena laporan barang habis pakai berdasarkan tanda terima barang tiap ruangan yang dikumpulkan.

3. Dalam hal pengelolaan permintaan mengenai inventaris selama ini pihak gudang dan ruangan menggunakan blanko permintaan inventaris, pihak ruangan akan mencatatkan jumlah permintaan inventaris dan diberikan kepada pihak gudang. Kemudian pihak gudang akan membuatkan laporan permintaan inventaris yang akan diberikan kepada Tata Usaha. Sehingga tidak terjaminnya data-data inventaris yang masuk dan yang keluar, karena sistem penyimpanan datanya tidak teratur dan masih mengandalkan kertas-kertas arsip.

Berdasarkan beberapa masalah yang telah dijabarkan, maka penulis mengusulkan sebuah sistem yang baru, sehingga dapat membantu pihak gudang Rumah Sakit Umum Daerah Sawahlunto. Pada sistem baru yang diusulkan, pihak gudang tidak lagi menggunakan kartu stock opname, untuk mengetahui jumlah sisa barang yang ada di gudang. Pada sistem yang baru penulis menggunakan database untuk penyimpanan. Pada saat pihak ruangan meminta barang yang dibutuhkannya, pihak gudang akan menginputkan permintaan dan akan tersimpan ke database, maka dengan otomatis jumlah barang yang ada di gudang akan dikurangi dengan jumlah barang yang diminta ruangan. Sehingga kesalahan mengenai jumlah sisa barang yang ada di gudang tidak terjadi lagi dan informasi mengenai jumlah barang yang akan dipesan pada bon pasar akan akurat dan sesuai dengan kebutuhan. Maka kesalahan dalam pembuatan laporan stock opname dan barang habis pakai dapat diatasi. Begitu juga dengan pendistribusian inventaris dari gudang ke ruangan dengan menggunakan sistem baru yang mengandalkan database data-data mengenai inventaris yang masuk dan keluar dari gudang menjadi teratur dan terjamin.

\subsection{Desain Sistem}

\subsubsection{Aliran Sistem Informasi(ASI) Baru} Pengadaan Barang Rumah Sakit Umum

\section{Daerah Sawahlunto}

Mengenai tahapan-tahapan data pengadaan dari gudang ke ruangan ini maka penulis akan menggambarkannya dalam aliran sistem informasi yang sedang berjalan pada Gudang Rumah Sakit Umum Daerah Sawahlunto pada gambar berikut: 
Penelitian Bidang Komputer Sains dan Pendidikan Informatika V2.i1(63-78)

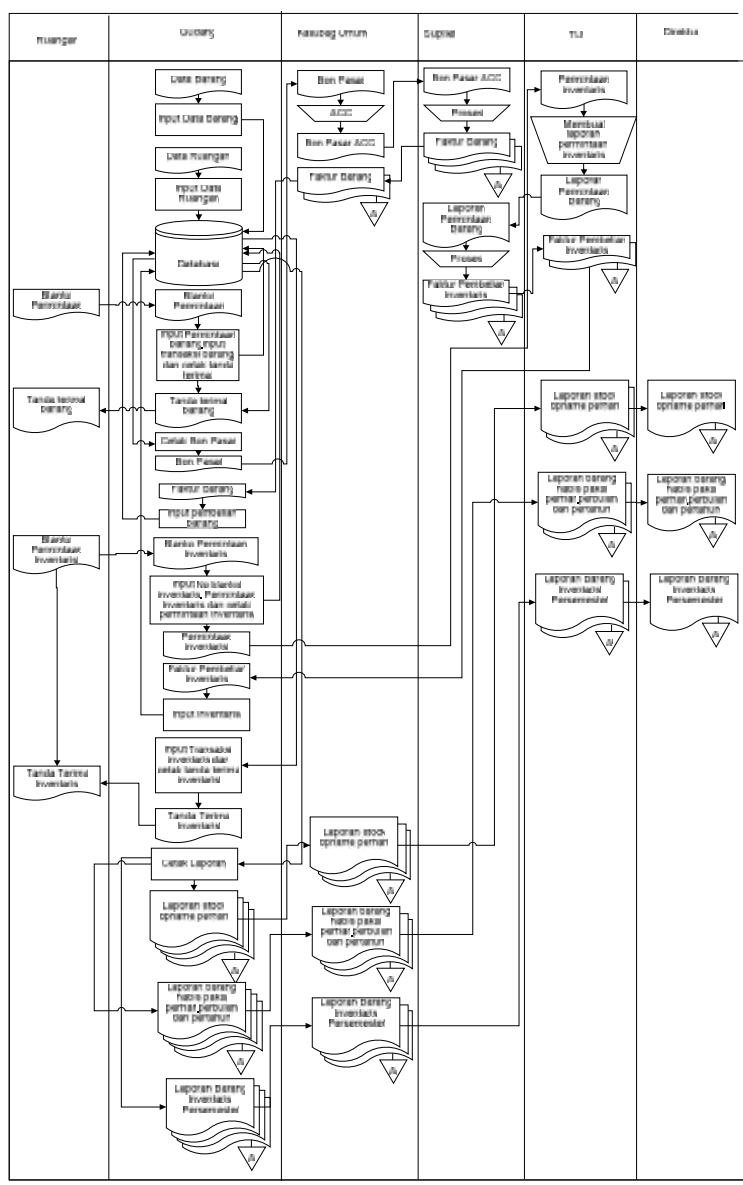

Gambar 3.2 Aliran Sistem Informasi Baru Pengadaan Barang Rumah Sakit Umum Daerah Sawahlunto

\subsubsection{Context Diagram}

Context Diagram adalah gambaran umum tentang suatu sistem yang terdapat di dalam suatu organisasi yang memperlihatkan batasan (boundary) sistem, adanya interaksi antara eksternal entity dengan suatu sistem, dan informasi secara umum mengalir di antara entity dan sistem. Context Diagram ini merupakan alat Bantu yang digunakan dalam menganalisa sistem yang akan dikembangkan yang terdiri atas sebuah lambang proses yang diberi nama dengan Sistem Informasi pengolahan data produksi yang diberi label 0 yang berinteraksi dengan empat entity, yaitu Ruangan, gudang, Kasubag Umum, dan TU

Adapun Context Diagram dari sistem informasi yang berjalan dapat dilihat pada Gambar dibawah ini:

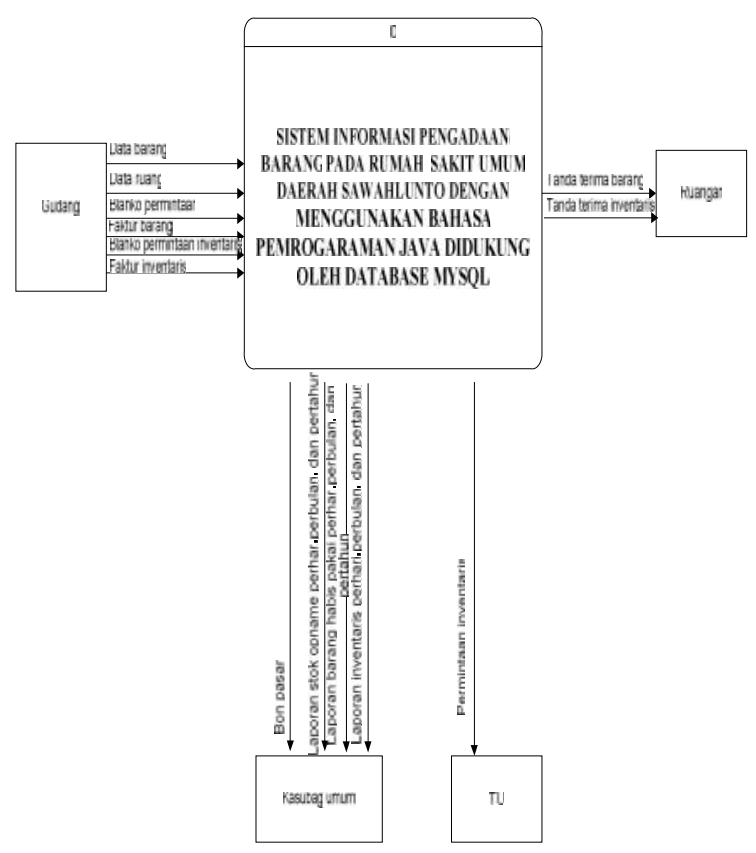

\section{Gambar 3.3 Context Diagram}

\subsubsection{Data Flow Diagram (DFD)}

Data Flow Diagram (DFD) adalah gambaran sistem secara logical. Gambaran ini tidak tergantung pada perangkat keras, perangkat lunak, struktur data atau organisasi file. Keuntungan menggunakan Data Flow Diagram (DFD) adalah untuk memudahkan 
Penelitian Bidang Komputer Sains dan Pendidikan Informatika V2.i1(63-78)

pemakai yang kurang menguasai bidang komputer untuk mengerti sistem yang akan dikembangkan.

Dengan mengacu kepada Context Diagram, dapat memperjelas proses yang terjadi adalah menguraikan proses tersebut ke dalam bentuk Data Flow Diagram (DFD). Sehingga pemakai yang masih awam mengerti bagaimana sistem yang dikembangkan dapat bekerja secara efektif dan efisien membantu pekerjaan sipemakai sistem.

Untuk lebih jelasnya dapat dilihat pada Gambar Data Flow Diagram (DFD) level 0 .

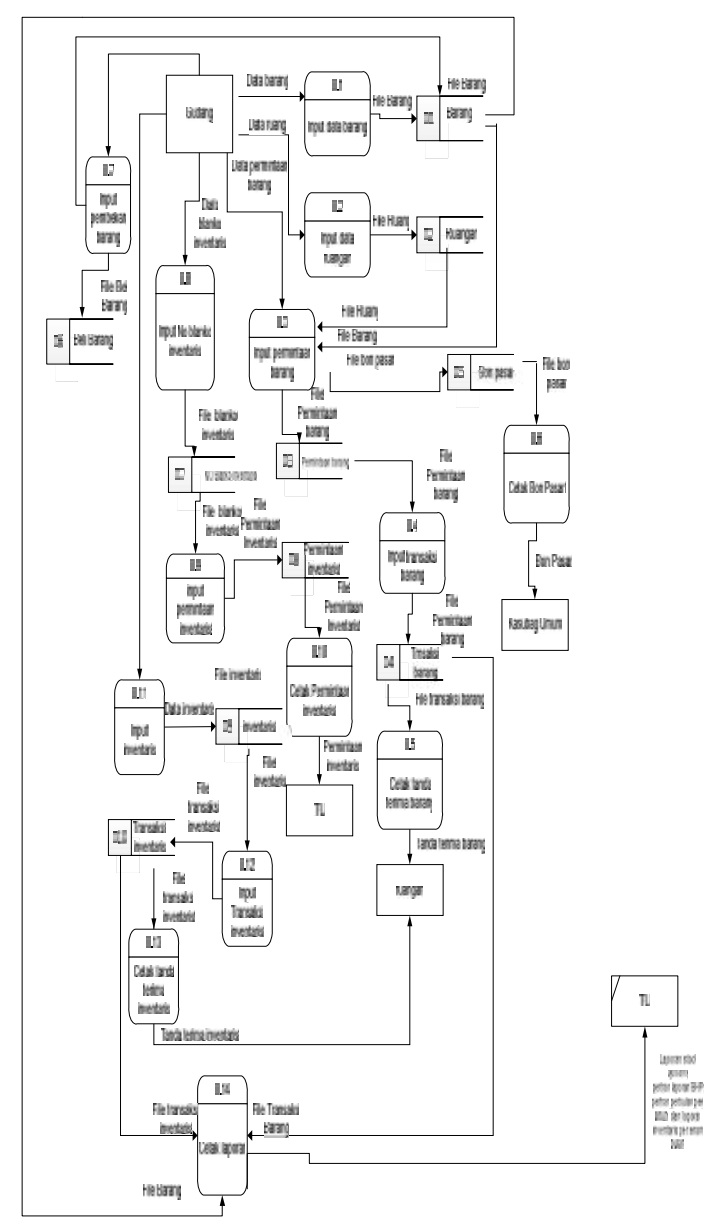

\section{Gambar 3.4 Data Flow Diagram (DFD)}

\section{Level 0}

\subsubsection{Entity Relationship Diagram (ERD)}

Entity Relationship Diagram digunakan untuk menjelaskan hubungan antar datadalam basis data berdasarkan persepsi adanya keterkaitan yang saling mendukung antara satu data dengan data yang lainnya. Untuklebih jelasnya, EntityRelationship Diagram (ERD) dapat dilihat pada Gambar dibawah ini :

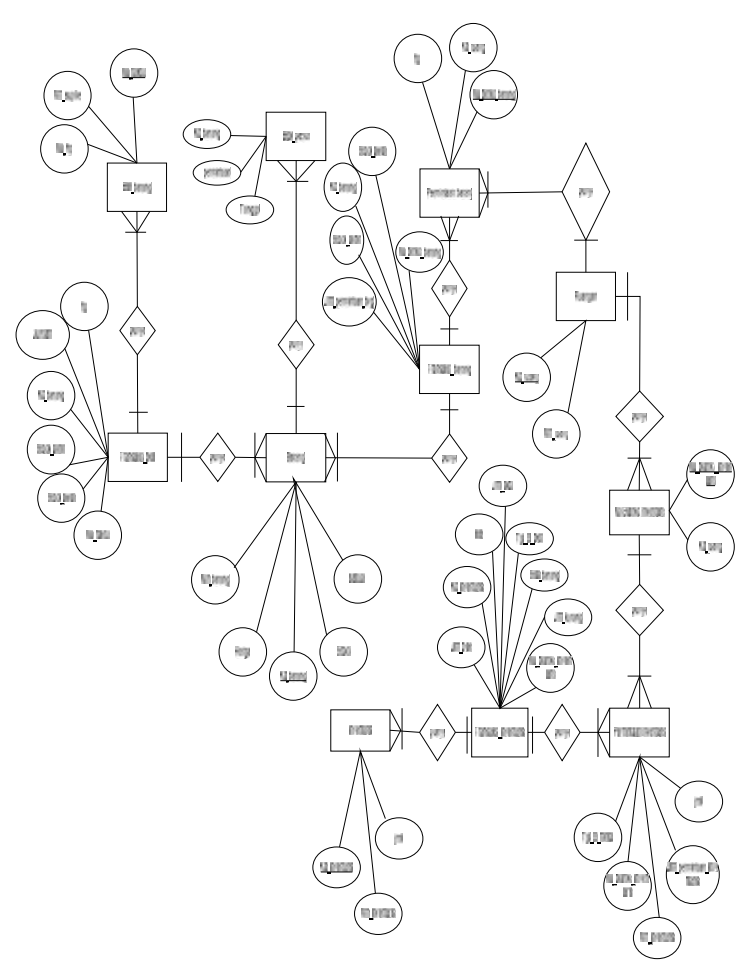

\section{Gambar 3.5 Entity Relationship Diagram} (ERD)

\subsubsection{Struktur Program}

Gambar 3.6 merupakan struktur 
program aplikasi yang dirancang secara keseluruhan.

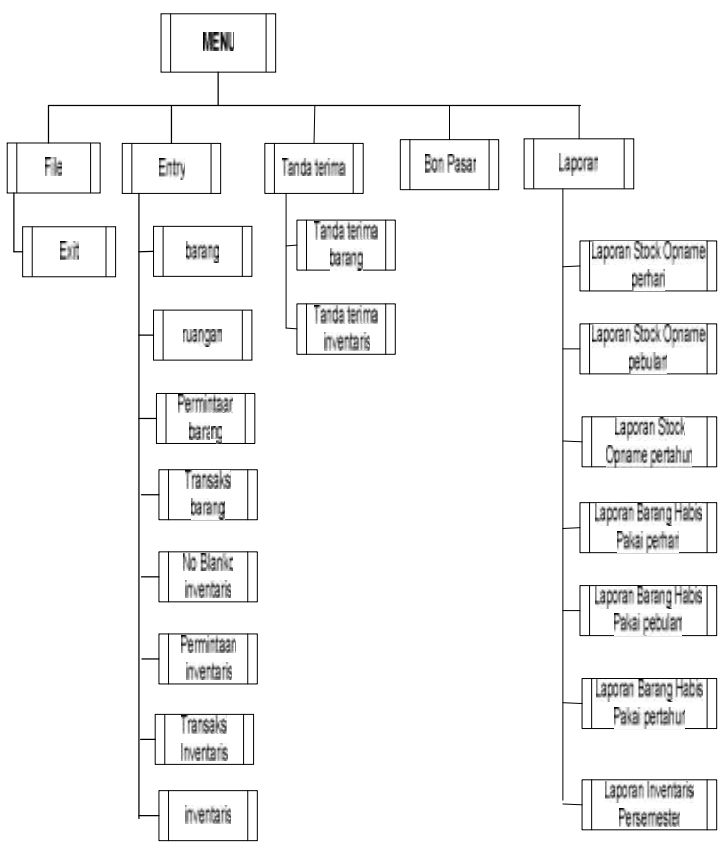

Gambar 3.6 Struktur Program

\section{IMPLEMENTASI DAN PENGUJIAN}

\subsection{Implementasi Sistem Informasi}

Tahap implementasi sistem merupakan salah satu tahap meletakkan sistem informasi supaya siap untuk dipakai. Dalam tahap ini berlangsung beberapa aktifitas secara berurutan yakni mulai dari menerapkan rencana implementasi, melakukan kegiatan implementasi, dan tindak lanjut implementasi.

Untuk melakukan sebuah implementasi maka di perlukan pembutan program komputer dengan menggunakan suatu aplikasi, yang dimaksud dengan pembuatan program kompoter adalah perancangan interface dan penulisan kode program sesuai dengan sistem yang telah di rancang. Sesuai dengan metodologi penelitian yang telah di buat sebelumnya maka perancangan yang telah ditetapkan sebelumnya di diagram alir data datri sistem yang dirancang.

\subsection{Menu Utama}

Form ini merupakan Jendela Menu Utama dari aplikasi Sistem Informasi pengandaan Barang Rumah Sakit Umum Daerah Sawahlunto. Dimana untuk bisa masuk ke sub menu entry, laporan dan informasi kita harus masuk ke jendela Menu Utama terlebih dahulu. Sub menu yang tersedia yaitu sub menu entry, laporan dan informasi. Form ini memudahkan kita untuk mengolah data atau hanya sekedar melihat data-data yang dibutuhkan. Form menu utama dapat dilihat pada Gambar 4.1

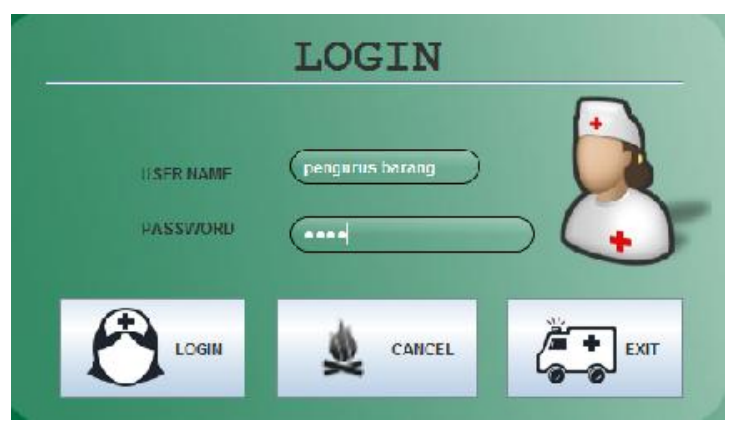

\section{Gambar 4.1 login}




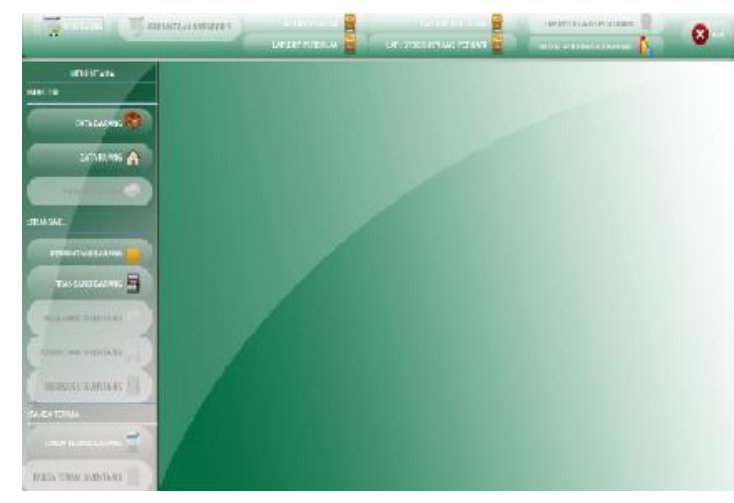

Gambar 4.2 Form Menu Utama

\subsection{Sub Menu Entry}

Dari menu utama menu paling kiri adalah menu entry dari semua data yang akan dipakai untuk operasi berikutnya.

1. Data barang

Merupakan menu entry data barang yang dimasukkan ke database melalui form ini, dengan ketentuan setiap barang memiliki kode yang berbeda. Form entry data barang dapat dilihat pada Gambar 4.3

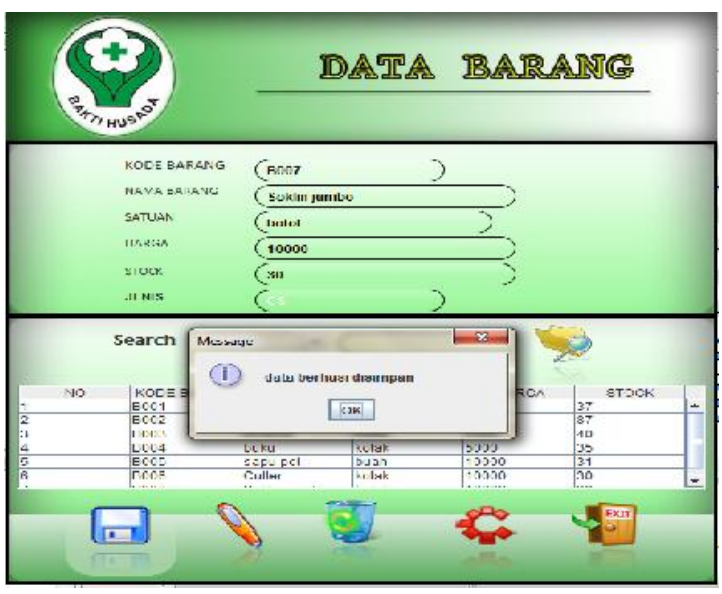

Gambar 4.3 Form Entry Barang

\section{Ruangan}

Merupakan form yang digunakan untuk memasukkan data nama-nama ruangan. Form entry data ruangan dapat dilihat pada Gambar 4.4

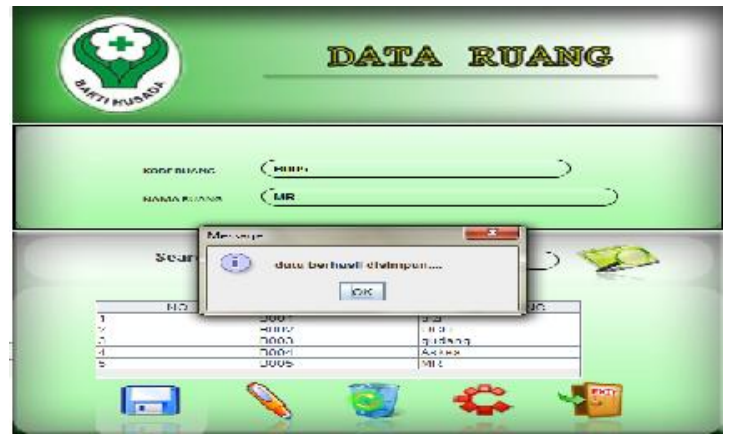

\section{Gambar 4.4 Form Entry Ruang}

3. Permintaan Barang

From yang digunakan untuk entry Nomor blanko barang bagi ruangan yang akan meminta barang ke gudang.

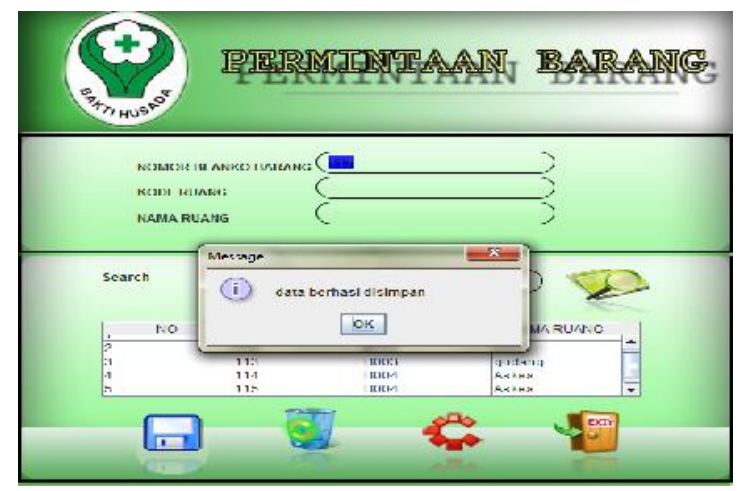

Gambar 4.5 Form Entry Permintaan

\section{Barang}

4. Entry Transaksi Barang

Form yang digunakan untuk menginputkan barang yang akan diminta oleh ruangan sesuai dengan nomor blanko barang. Pada form ini barang yang diminta akan langsung 
Penelitian Bidang Komputer Sains dan Pendidikan Informatika

dikurangkan otomatis dengan stock barang yang ada di gudang. Sehingga barang yang di bawah batas maksimum akan masuk pada bon pasar.

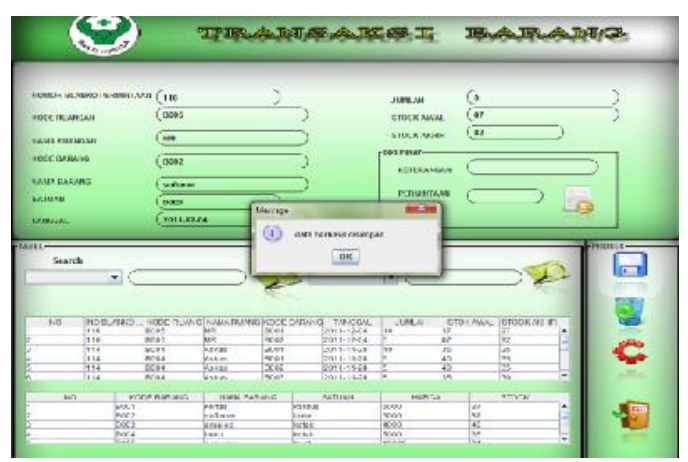

\section{Gambar 4.6 Form Entry Transaksi}

\section{Barang}

5. Entry Pembelian Barang

Form yang digunakan untuk menginputkan barang yang akan dibeli. Pada form ini jumlah stock pada barang akan bertambahdengan otomatis sesuai dengan jumlah barang yang di beli.

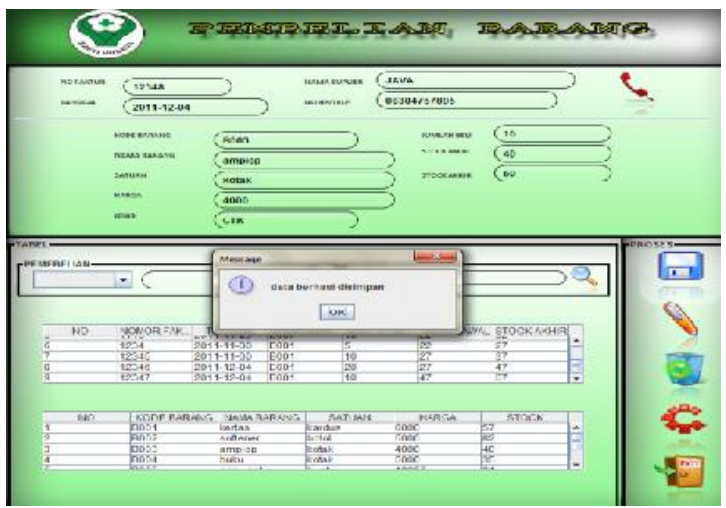

\section{Gambar 4.7 Form Entry Pembelian}

\section{Barang}

6. Entry Inventaris

Merupakan menu entry data inventaris yang dimasukkan ke database melalui form ini, dengan ketentuan setiap inventaris memiliki kode yang berbeda

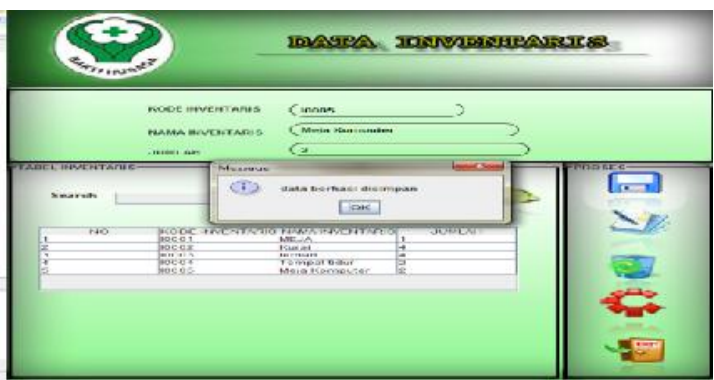

\section{Gambar 4.8 Form Entry inventaris}

7. Entry Nomor Blanko Inventaris

From yang digunakan untuk entry Nomor blanko inventaris bagi ruangan yang akan meminta inventaris ke gudang.

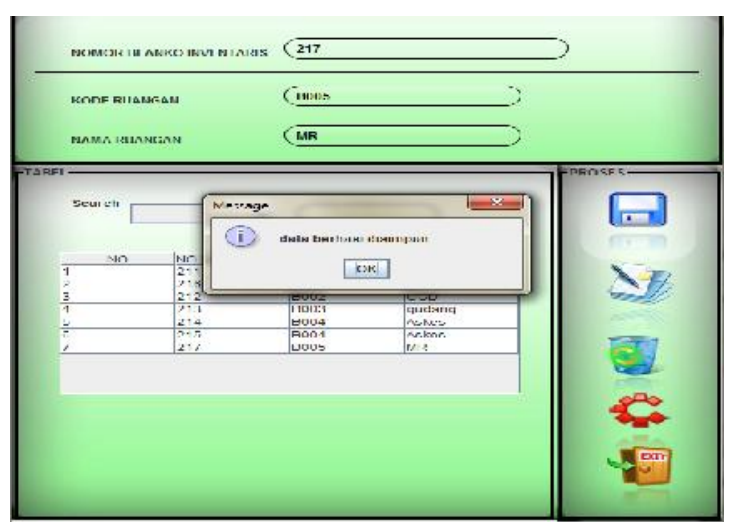

\section{Gambar 4.9 Form EntryNo Blanko inventaris}

8. Entry Permintaan Inventaris 
Form yang digunakan untuk menginputkan inventaris yang dibutuhkan oleh ruangan sesuai dengan nomor blanko inventaris yang dimiliki ruangan.

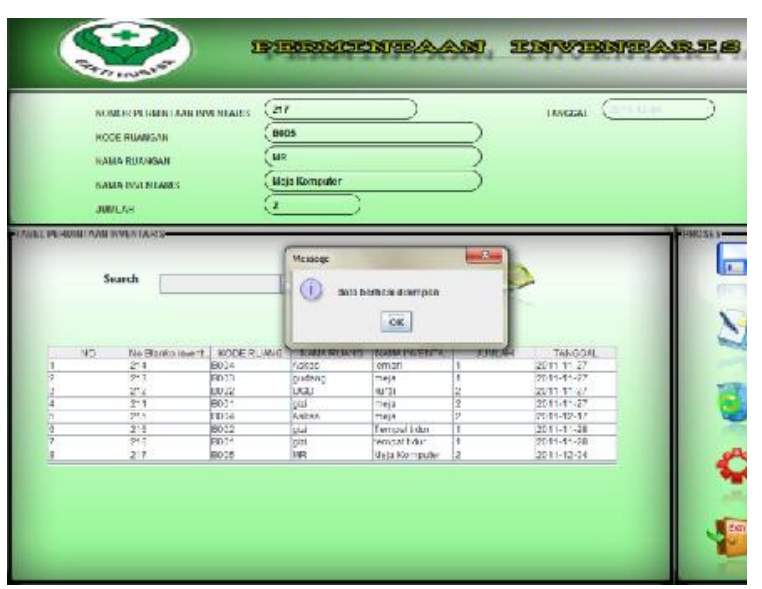

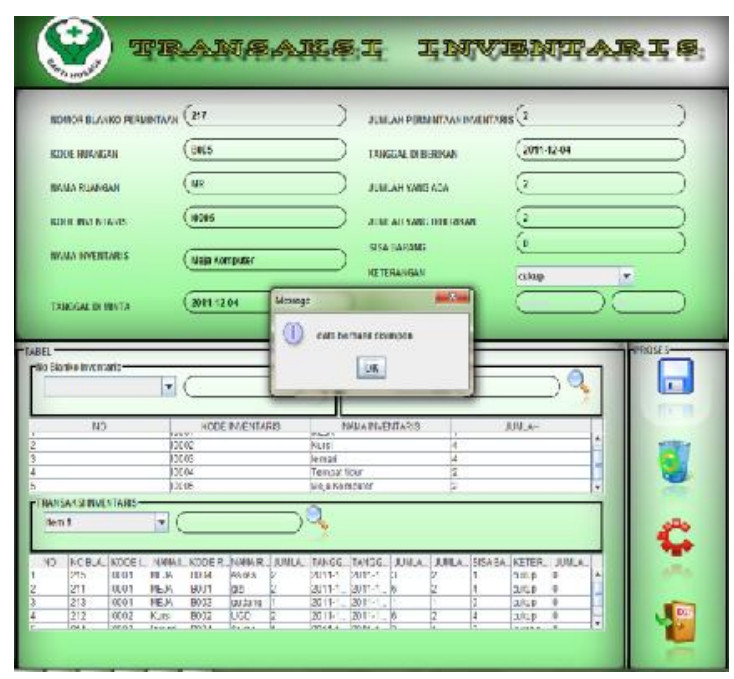

Gambar 4.11 Form Entry Transaksi inventaris

\subsection{Sub Menu Laporan}

Pada sub menu laporan dapat ditampilkan tanda terima barang, tanda terima inventaris, bon pasar, permintaan inventaris, laporan barang habis pakai perhari, laporan habis pakai perbulan, laporan habis pakai pertahun, dan laporan inventaris perenam bulan sebelum kita mencetaknya ke printer. Laporan-laporan yang dihasilkan antara lain: 
Penelitian Bidang Komputer Sains dan Pendidikan Informatika V2.i1(63-78)

1. Tanda Terima Barang

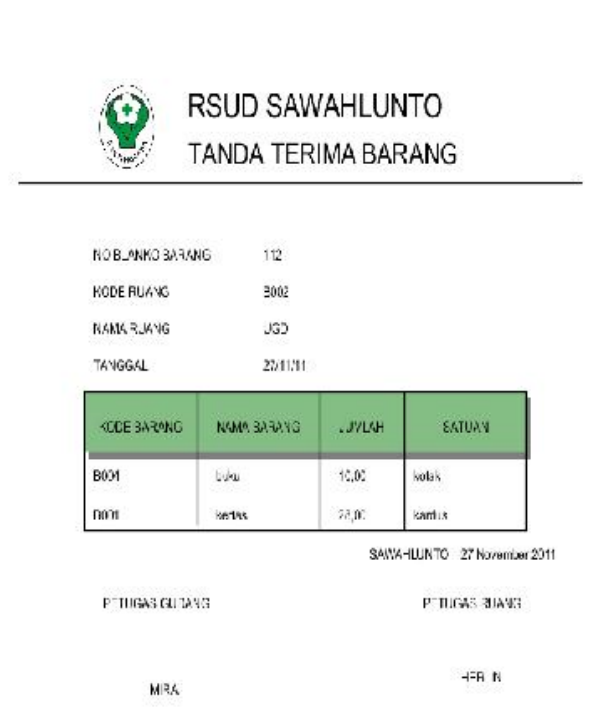

Gambar 4.12 Tanda Terima Barang

2. Bon Pasar

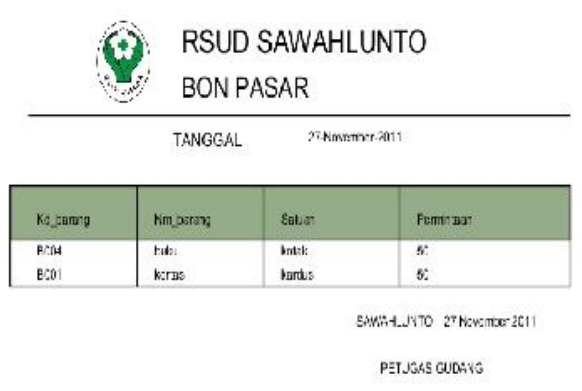

Gambar 4.13 Bon Pasar
3. Permintaan Inventaris

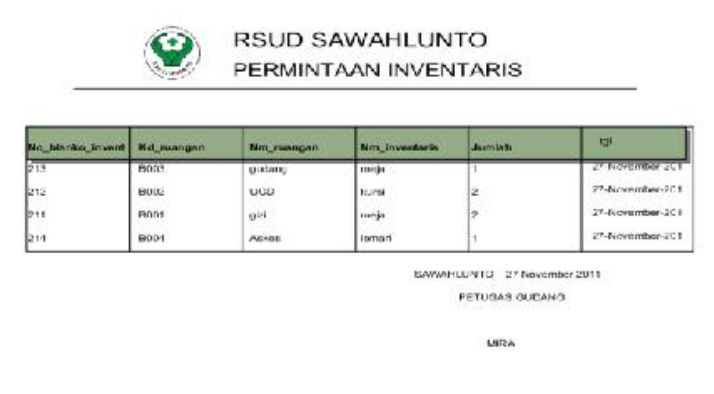

Gambar 4.14 Permintaan Inventaris

4. Tanda terima Inventaris

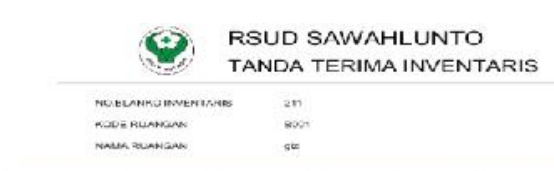

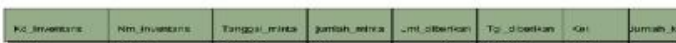
He vers cuave

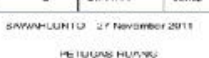

teivers num:

|crem

\section{Gambar 4.15 Tanda Terima \\ Inventaris}

5. Laporan Stock Opname Perhari

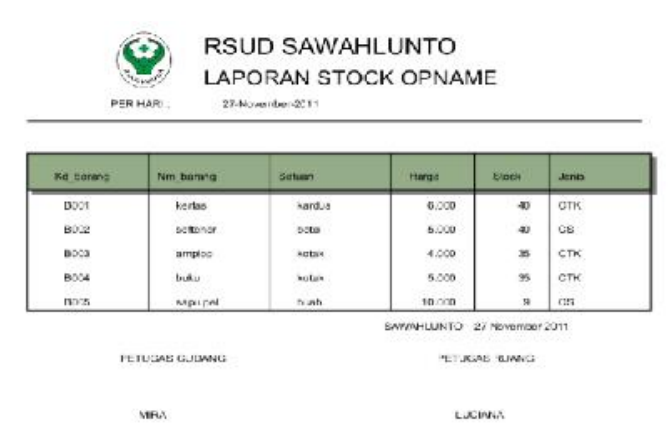

Gambar 4.16 Laporan Stock Opname

Perhari 
Penelitian Bidang Komputer Sains dan Pendidikan Informatika V2.i1(63-78)

6. Laporan Barang Habis Pakai

Perhari

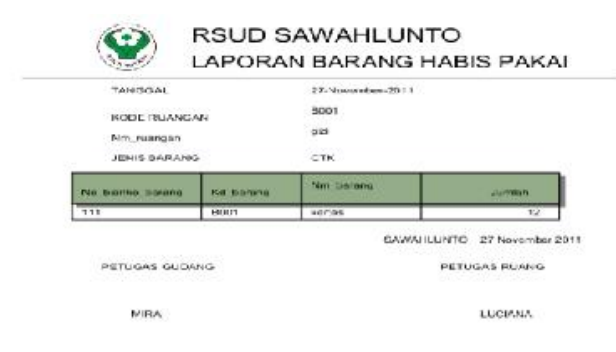

Gambar 4.17 Laporan Barang Habis

Pakai Perhari

7. Laporan Barang Habis Pakai

Perbulan

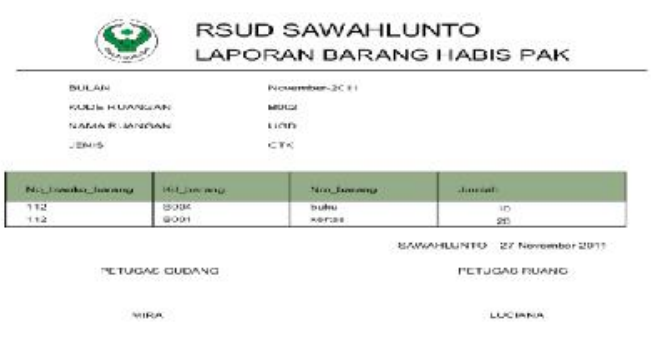

Gambar 4.18 Laporan Barang Habis

Pakai Perbulan
8. Laporan Barang Habis Pakai

Pertahun

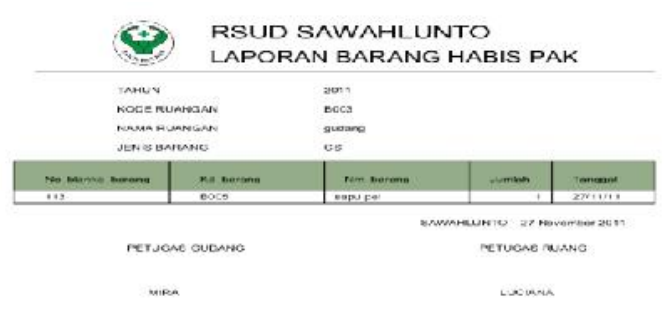

Gambar 4.19 Laporan Barang Habis Pakai Pertahun

9. Laporan Inventaris Perenam Bulan

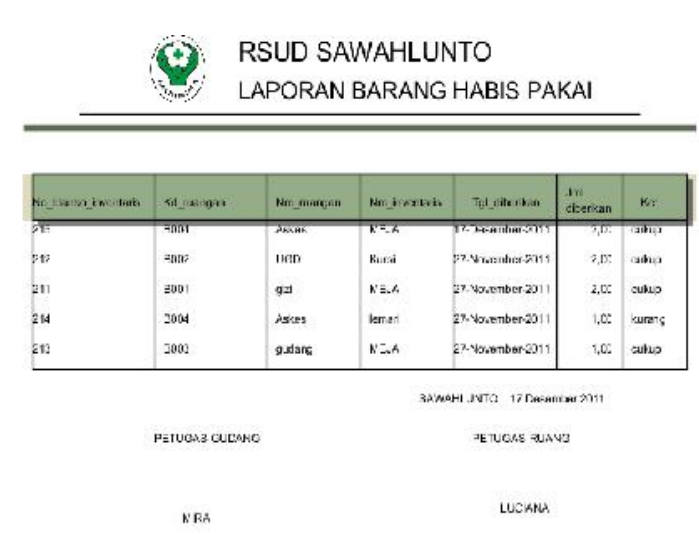

Gambar 4.20 Laporan Inventaris Perenam bulan

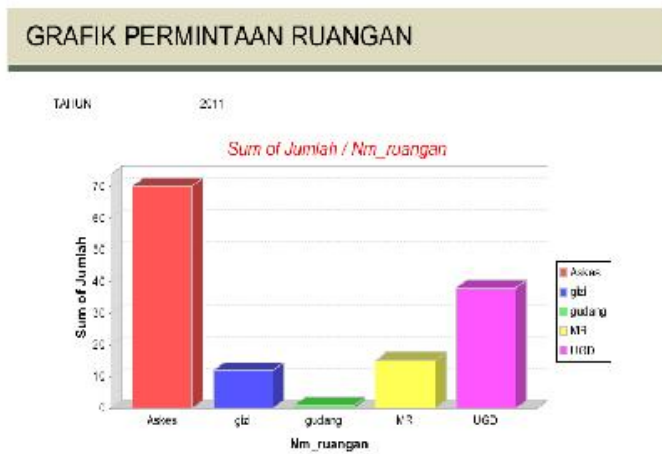


Gambar 4.21 Laporan Grafik Permintaan Barang Ruangan

\section{KESIMPULAN DAN SARAN}

\section{Kesimpulan}

Dari uraian dan penjelasan yang telah diterapkan pada bab-bab sebelumnya serta didukung hasil analisa terhadap sistem informasi pengadaan barang pada Rumah Sakit Umum Daerah Sawahlunto ditemukan bahwa :

1. Dengan penggunaan sistem informasi berbasis komputer memberikan manfaat bagi pihak gudang yakni pihak gudang dapat menyajikan informasi mengenai barang yang akan di order, sisa barang yang masih ada di gudang, dan jumlah permintaan barang setiap ruangan dengan benar dan cepat.

2. Dengan memakai komputer dan Bahasa pemrograman java dan database opensource yang mendukung dalam pengadaan barang, maka penyajian data barang yang dibutuhkan lebih cepat sesuai dengan prosedur yang diterapkan

3. Penerapan teknologi informasi dalam pengolahan data secara optimal dan kinerja yang lebih teratur dapat menghasilkan laporan Barang Habis Pakai, stock opname dan inventaris barang yang sesuai dengan transaksi permintaan barang dan inventaris yang terjadi.

\section{Saran- Saran}

Dari kesimpulan di atas dapat dilihat hasil dari penelitian terhadap pengadaan barang. Selain itu perlu dikemukakan beberapa saran yang diharapkan dapat menjadi bahan pertimbangan lebih lanjut dalam upaya peningkatan pelayanan, kinerja, ataupu untuk upaya pengembangan sistem selanjutnya.

Saran-saran yang dirasa perlu yaitu:

1. Terlebih dahulu harus dilakukan penyesuaian dengan sistem yang baru ini sehingga akan terasa keunggulanya dan kelebihanya dibanding dengan sistem yang lama. Misalnya dengan memberikan masa uji coba selama 1 tahun.

2. Memberikan arahan kepada petugas gudang yang akan menggunakan sistem yang baru ini.

3. Dilakukannya peninjauan ulang terhadap sistem yang baru sehingga jika terdapat kekurangan atau kelemahan dari sistem yang baru ini maka dilakukan perbaikan.

\section{DAFTAR PUSTAKA}

Jogiyanto HM.2005. Pengenalan Komputer, Ed.V, Yogyakarta:Andi Offset. 
Penelitian Bidang Komputer Sains dan Pendidikan Informatika V2.i1(63-78)

Jogiyanto HM.2008.Metodologi Penelitian

Sistem Informasi. Yogyakarta:Andi

Offset.

Kadir, Abdul. 2008. Dasar Perancangan \& implementasi. . Yogyakarta:Andi

Offset

Mcleod, Raymond. George P Shell.2007.Sistem Informasi

Manajemen. Jakarta:Indeks

Sanjaya, Ridwan. 2004. Pengolahan

Database MySQL 5 Dengan

java.Semarang:Andi 